\title{
Edycje źródet staropolskich w sytuacji braku podstawowych zespołów archiwalnych (Testamenty szlachty Prus Królewskich z XVII wieku, opracowanie i uydanie Jacek Koualkouski i Wiesław Nowosad, Wydawnictwo DiG, Warszawa 2013, ss. 436, seria wydawnicza: „Szlachta i ziemiaństwo na ziemiach dawnej Rzeczypospolitej”)
}

\section{(c) $($ ) $\ominus$}

http://dx.doi.org/10.12775/KLIO.2014.025

$\int$ ednym z zasadniczych powodów niedostatków w badaniach nad różnorodnymi aspektami dziejów szlachty polskiej w okresie wczesnonowożytnym jest bez wątpienia stan zachowania bazy źródłowej. Jak już niejednokrotnie podkreślano w literaturze historycznej, w wyniku zawieruch dziejowych, w szczególności zaś drugiej wojny światowej, bezpowrotnie utracone zostały liczne materiały źródłowe do dziejów stanu uprzywilejowanego. Stwierdzenie to odnosi się zwłaszcza do podstawowych zespołów źródłowych do badań nad szlachtą poszczególnych prowincji, województw i ziem Rzeczypospolitej - ksiąg sądów szlacheckich ${ }^{1}$. To właśnie w księgach sądowych - ziemskich, grodzkich, podkomorskich, trybunalskich - szlachta wpisywała znakomitą część wytwarzanej przez siebie dokumentacji. Poza zapisami spraw spornych oraz rozmaitych transakcji majątkowych, szlachta podawała do określonych serii ksiąg dokumenty wytworzone w większości $\mathrm{w}$ swych dworach (zapisy cum ingrossatione, oblaty) ${ }^{2}$, m.in. akty divisionis

${ }^{1}$ Zob. m.in.: A. Wolff, Akta partykularne przedrozbiorowe Archiwum Gtównego 1381-1835, [w:] Straty archiwów i bibliotek warszawskich w zakresie rękopiśmiennych źródet historycznych, t. 1, Archiwum Gtówne Akt Dawnych, Warszawa 1957, s. 175-221.

2 O rodzajach dokumentów wnoszonych przez szlachtę do ksiąg grodzkich i zapisach w tychże księgach szeroko ostatnio: J. Łossowski, Kancelaria grodzka chetmska od XV do XVIII wieku. Studium o urzędzie, dokumentacji, jej formach i roli w życiu spoteczeństwa staropolskiego, Lublin 2004, szczególnie s. 165-208. 
bonorum terrestrium ${ }^{3}$, inwentarze rerum mobilium ${ }^{4}$, inwentarze dóbr ziemskich $^{5}$, kontrakty kupna-sprzedaży i rozmaite intercyzy związane z obrotem ziemią $^{6}$, kontrakty przedślubne ${ }^{7}$, akty ostatniej woli. W wyniku wspomnianych zniszczeń nie dysponujemy obecnie szlacheckimi księgami sądowymi z różnych części dawnej Rzeczypospolitej. Tak np. dla położonego w centralnej części państwa jednego z największych województw - sandomierskiego - nie istnieje dziś zbiór ponad 3000 ksiąg i fascykułów z okresu od średniowiecza do końca XVIII wieku, a jedynymi ocalałymi księgami tego województwa są zachowane w niedużej liczbie księgi ziemskie i grodzkie jednego z siedmiu powiatów województwa - pilzneńskiego ${ }^{8}$. Całkowita

${ }^{3}$ Por.: J. Pielas, Podziaty majątkowe szlachty koronnej w XVII wieku, Kielce 2013, s. $39-82$.

${ }^{4}$ Zob. przede wszystkim: A. Pośpiech, Putapka oczywistości. Pośmiertne spisy ruchomości szlachty wielkopolskiej z XVII wieku, Warszawa 1992; J. Dumanowski, Świat rzeczy szlachty wielkopolskiej $w$ XVIII wieku, Toruń 2006.

${ }_{5}^{5}$ Inwentarze dóbr szlacheckich powiatu kaliskiego, t. 1: Od XVI do potowy XVIII w., wyd. W. Rusiński, Wrocław 1955, [wstęp] s. XVIII-XXIX; Inwentarze dóbr ziemskich województwa krakowskiego 1576-1700. Wybór z ksiag relacyj grodu krakowskiego, oprac. A. Kamiński, A. Kiełbicka, S. Pańków, Warszawa 1956, [słowo wstępne] s. 5-19 i ostatnio: Źródta i materiaty do dziejów szlachty województwa sandomierskiego w XVI-XVIII wie$k u$; t. 2: Inwentarze dóbr ziemskich z XVII-XVIII wieku (cz. 1), wstęp i oprac. J. Pielas, Kielce 2013, s. VII-XI.

${ }^{6}$ Zob. przede wszystkim: M. Wąsowicz, Kontrakty lwowskie w latach 1676-1686, Lwów 1935; S. Siegel, Kontrakty lwowskie w latach 1717-1724, Lwów 1935; J. Bielecka, Kontrakty lwowskie w latach 1768-1775 (wptyw pierwszego rozbioru Polski, 1772 r., na kontrakty lwowskie), Poznań 1948; A. Pośpiech, Majętności na sprzedaz, Szlachecki handel ziemiq i przemiany struktury majątkowej $w$ powiecie kaliskim $w$ latach 1580-1655, Wrocław 1989; H. M. Łaszkiewicz, Dziedzictwo czy towar? Szlachecki handel ziemiq w powiecie chetmskim w II potowie XVII wieku, Lublin 1998; P. Klint, Szlachecki obrót ziemia w powiecie kcyńskim w latach 1626-1655, Wrocław 2012.

${ }^{7}$ M.in.: M. Lubczyński, Zawieranie matżeństw przez szlachtę $w$ świetle intercyz przedslubnych oblatowanych $w$ krakowskich ksieggach grodzkich w latach 1680-1730, [w:] Wesela, chrzciny i pogrzeby w XVI-XVIII wieku. Kultura życia i śmierci, red. H. Suchojad, Warszawa 2001, s. 137-156; K. Sulej, Mariaże magnackie w XVI-XVIII wieku na podstawie intercyz przedślubnych, [w:] Spoteczeństwo staropolskie. Seria nowa, t. 3: Spoteczeństwo a rodzina, red. A. Karpiński, Warszawa 2011, s. 63-96.

${ }^{8}$ Źródta i materiaty do dziejów szlachty województwa sandomierskiego w XVI-XVIII wieku, t. 1: Rejestry pospolitego ruszenia szlachty sandomierskiej z XVII wieku, wstęp i oprac. J. Pielas, Kielce 2009, s. XV-XVI. 
zatrata spotkała również księgi pobliskich Sandomierszczyźnie powiatów piotrkowskiego i radomszczańskiego, należących do województwa sieradzkiego ${ }^{9}$. Historycy nie mogą również skorzystać dziś z analogicznych zbiorów źródeł z szeregu ziem i powiatów wchodzących w skład Mazowsza oraz dwu województw Prus Królewskich - chełmińskiego i pomorskiego ${ }^{10}$. Ogromu tych strat dopełnia całkowite niemalże zniszczenie akt Trybunału Koronnego obu kadencji - piotrkowskiej i lubelskiej ${ }^{11}$.

W tej sytuacji za szczególnie cenne należy uznać inicjatywy edytorskie stawiające sobie za cel wydobycie z dostępnych dziś zasobów archiwalnych źródeł odnoszących się do tych obszarów ówczesnej Rzeczypospolitej, które poniosły całkowite lub znaczne straty w księgach sądów szlacheckich. Udostępnienie tych źródeł drukiem pozwala na prezentację z imienia i nazwiska szlachty zamieszkującej te obszary i stanowi dobry punkt wyjścia dla dalszych badań nad dziejami braci szlacheckiej z tych terenów. W związku z rozproszeniem materiału źródłowego dla wspomnianych części Rzeczypospolitej, w zasadzie oczywiste wydaje się przyjęcie koncepcji katalogowania, opracowywania i wydawania w odrębnych edycjach książkowych poszczególnych rodzajów źródeł - tych najbardziej wartościowych z punktu widzenia współczesnych badań historycznych. W 2003 roku tego typu program wydawniczy podjęty został przez piszącego te słowa dla województwa sandomierskiego w ramach serii „Źródła i materiały do dziejów szlachty województwa sandomierskiego w XVI-XVIII wieku”. W jej obrębie ukazały się dotąd rejestry pospolitego ruszenia szlachty sandomierskiej z XVII wieku, wybór inwentarzy dóbr ziemskich z tego województwa z XVII-XVIII w. oraz aktów divisionis bonorum terrestrium z XVII stulecia ${ }^{12}$. Z satysfakcją należy odnotować, że także w odniesieniu do Prus

9 Urzędnicy województw tęczyckiego i sieradzkiego XVI-XVIII wieku. Spisy, oprac. E. Opaliński, H. Żerek-Kleszcz, red. A. Gąsiorowski, Kórnik 1993, s. 13.

10 Zob.: A. Wolff, op. cit.; Urzędnicy Prus Królewskich XV-XVIII wieku. Spisy, oprac. K. Mikulski, red. A. Gąsiorowski, Wrocław-Warszawa-Kraków 1990, s. 37.

${ }_{11}$ M.in.: M. Stankowa, Ocalate fragmentu akt Trybunatu Koronnego Lubelskiego w Wojewódzkich Archiwum Państwowym w Lublinie 1578-1793, „Archeion” 1964, t. 40, s. $105-129$.

12 Por. przyp. 5, 8 oraz Źródta i materiaty do dziejów szlachty województwa sandomierskiego w XVI-XVIII wieku, t. 3: Akty podziatów dóbr ziemskich szlachty sandomierskiej z XVII wieku, wstęp i oprac. J. Pielas, Kielce 2014. 
Królewskich - prowincji również ubogiej pod względem stanu zachowania ksiąg sądów szlacheckich - w ostatnich latach podjęte zostały tego rodzaju starania. W 2013 roku otrzymaliśmy bowiem wydawnictwo testamentów szlachty Prus Królewskich z XVII wieku jako efekt wysiłku edytorskiego Jacka Kowalkowskiego i Wiesława Nowosada. Książka Testamenty szlachty Prus Królewskich z XVII wieku, oprac. i wyd. J. Kowalkowski, W. Nowosad, Warszawa 2013, ukazała się w ramach serii „Szlachta i ziemiaństwo na ziemiach dawnej Rzeczypospolitej"13 i została sfinansowana ze środków Narodowego Programu Rozwoju Humanistyki i Polskiego Towarzystwa Historycznego. Wydawcy XVII-wiecznych testamentów szlachty Prus Królewskich nawiązali swą pracą do książkowych edycji szlacheckich testamentów, które - szczególnie w okresie ostatnich kilkudziesięciu lat pojawiły się w obiegu naukowym ${ }^{14}$. Jak podkreślili w pierwszych słowach wstępu do wydawnictwa wyżej wymienieni badacze, przygotowana przez nich edycja stanowi kolejny w polskiej historiografii „zbiór dokumentów testamentowych w układzie określonym kryteriami: grupa społeczna - terytorium - czas - źródła”, jednocześnie zaś jest pierwszym obejmującym testamenty szlachty Prus Królewskich (s. 9).

Omawiana edycja źródłowa to znacznych rozmiarów pozycja książkowa (ss. 436), składająca się z wykazu publikowanych testamentów, wstępu (s. 9-56), wykazu skrótów, w tym odnoszących się do źródeł i literatury oraz skrótów używanych w tekstach źródłowych (s. 57-62), zasadniczej części w postaci 111 dokumentów źródłowych (s. 64-374) i następnie wykazu testamentów odnalezionych, lecz nieuwzględnionych w publikacji

${ }^{13}$ W serii tej ukazała się także książka K. Ślusarka, W przededniu autonomii. Wtasność ziemska i ziemiaństwo w potowie XIX wieku, Warszawa 2013.

${ }_{14}$ Zob.: O. Hedemann, Testamenty brastawsko-dziśnieńskie XVII-XVIII w. jako źródto historyczne, Wilno 1935; M. Borkowska, Dekret w niebieskim ferowany parlamencie. Wybór testamentów z XVII-XVIII wieku, Kraków 1984; U. Augustyniak, Testamenty ewangelików reformowanych $w$ Wielkim Księstwie Litewskim, Warszawa 1992; Testamenty szlachty krakowskiej XVII-XVIII w. Wybór tekstów źródtowych z lat 1650-1799, oprac. A. Falniowska-Gradowska, Kraków 1997; Cui contingit nasci, restat mori. Wybór testamentów staropolskich z województwa sandomierskiego, oprac. M. Lubczyński, J. Pielas, H. Suchojad, Warszawa 2005; Testamenty szlacheckie z ksiag grodzkich wielkopolskich z lat 1631-1655, wyd. P. Klint, Poznań-Wrocław 2008; Testamenty szlacheckie z ksiag grodzkich wielkopolskich 1657-1680, wyd. P. Klint, Wrocław 2011. 
(s. 375), słowniczka wybranych słów i zwrotów staropolskich (s. 376-380), bibliografii wykorzystanych źródeł rękopiśmiennych, drukowanych i opracowań (s. 381-391) oraz indeksu osób, zgromadzeń zakonnych i miejscowości (s. 392-436).

Założenia edycji zostały przedstawione w obszernym wstępie. Rozpoczyna go przypomnienie dotychczasowego dorobku polskiej historiografii w zakresie publikacji testamentów szlacheckich $\mathrm{w}$ formie książkowej oraz edycji pojedynczych dokumentów i zebranych w niewielkich grupach rodzinnych. Wydawcy uzupełnili spis wydanych testamentów, ogłoszony niegdyś przez opracowujących wydawnictwo testamentów sandomierskich, wychwytując pominięte $\mathrm{w}$ tej bibliografii pojedyncze szlacheckie akty ostatniej woli (s. 10, przyp. 9) ${ }^{15}$, a także podając najnowsze tego typu edycje (s. 10-11, przyp. 10) ${ }^{16}$. Podobnie uczynili w zakresie literatury powstałej na podstawie testamentów szlacheckich ${ }^{17}$. W dalszej kolejności J. Kowalkowski i W. Nowosad dokonali skrupulatnego przeglądu uprzednio opublikowanych testamentów przedstawicieli szlachty pruskiej

${ }^{15}$ Cui contingit nasci..., s. 14-17. Por. także: M. Mikuła, Obraz Boga w testamentach szlacheckich doby nowożytnej, [w:] Religijnośc. Wymiar prywatny i publiczny, red. W. Szymborski, P. F. Nowakowski, Kraków 2007, s. 224, przyp. 3-5.

${ }^{16}$ Do tego uzupełnienia wypada jeszcze dodać: Testament Jan Baptysty Cellariego z 1661 roku, wyd. M. Janik, „Zeszyty Historyczne Akademii im. Jana Długosza w Częstochowie” 2006, t. 9, s. 93-102; A. Szymanek, Barbara Tartowa, starościna sochaczewska, w świetle testamentu z 1613 roku, [w:] VIII Janowieckie Spotkania Historyczne: Tartowie. Z dziejów kulturalnych, gospodarczych i politycznych rodu, t. 2, red. H. Gmiterek, A. Szymanek, Janowiec 2009, s. 148-154 (ponowne wydanie testamentu Barbary z Dulskich Tarłowej); Testamenty Janusza Radziwitta, podczaszego litewskiego, kasztelana wileńskiego, wyd. W. Kaczorowski, „Opolskie Studia Administracyjno-Prawne” 2010, [t. 7], s. 271-289; Testament Andrzeja Batorego z 1599 r., wyd. J. Kowalkowski, „Komunikaty Warmińsko-Mazurskie” 2012, nr 4, s. 647-664.

17 Zob. także: M. Mikuła, op. cit., s. 223-244; K. Wiszowata, Testamenty jako źródto historyczne, „Białostockie Teki Historyczne” 2009, t. 7, s. 25-38; B. Popiołek, „Na ratunek duszy mojej" - pobożne fundacje w świetle testamentów staropolskich XVII-XVIII w., [w:] Fundator i mecenas. Magnateria Rzeczypospolitej $w$ XVI-XVIII wieku, red. E. DubasUrwanowicz, J. Urwanowicz, Białystok 2011, s. 43-60; J. Pielas, Podziaty majątkowe...; D. Burdzy, Zapisy testamentowe Marcina Kromera dla kościołów kolegiackich w Sandomierzu, Wiślicy i Kielcach (1589 rok), „Między Wisłą a Pilicą. Studia i Materiały Historyczne” 2013, t. 14 , s. $11-25$. 
oraz literatury, w tym niemieckiej, która wykorzystywała akty ostatniej woli szlachty tej prowincji, określili zakres merytoryczny edycji i zasięg kwerendy archiwalnej. Istotne miejsce - co stanowi niewątpliwie mocną stronę edycji - poświęcili prezentacji budowy i zawartości publikowanych testamentów. Przeanalizowali zatem pod względem ilościowym i treściowym zasadnicze elementy konstrukcyjne aktów ultimae voluntatis (inwokacja dewocyjna, intytulacja $\mathrm{z}$ promulgacją, arenga, rozporządzenie w kwestii duszy i losów ciała po śmierci, w tym legaty pobożne i wizja pogrzebu moribunda, dyspozycja majątkowa, pożegnanie, wyznaczenie egzekutorów, formuła actum et datum wraz z podpisami testatora i świadków), podając dla części z nich obrazujące poszczególne zjawiska czytelne zestawienia. Wstęp kończy przedstawienie zasad przygotowania tekstów do druku wraz z odniesieniem się do instrukcji wydawniczej z 1953 roku.

Przystępując do omówienia edycji testamentów szlachty Prus Królewskich, chciałbym w pierwszej kolejności odnieść się do kwestii niewątpliwie podstawowej dla wydawców, a więc stanu zachowania bazy źródłowej i zakresu kwerendy archiwalnej.

Jak już zaznaczyłem, a szerzej wypowiedzieli się o tym sami wydawcy (s. 25), nie dysponujemy obecnie większością podstawowych źródeł do badań nad szlachtą Prus Królewskich w okresie staropolskim. Już w XVII i pod koniec XVIII wieku bowiem zaginęły lub spaliły się całkowicie księgi ziemskie i grodzkie województw chełmińskiego i pomorskiego, istniejące zaś w Archiwum Państwowym w Gdańsku księgi ziemskie sztumskie i grodzkie kiszporskie (dzierzgońskie) dokumentują działalność szlachty najmniejszego z województw tej prowincji - malborskiego, na terenie którego zresztą dominowała własność królewska i miejska. W związku z tym prócz poszukiwań aktów ostatniej woli w 37 księgach protokołów i indukt sądu grodzkiego dzierzgońskiego z lat 1633-1772 oraz w 7 księgach sądu ziemskiego w Sztumie z lat 1618-1767 - jak najbardziej słusznie zdecydowano się na znaczące rozszerzenie kwerendy źródłowej. Objęła ona imponującą liczbę zespołów źródłowych, zarówno wytworzonych na terenie Prus Królewskich, poza ich obszarem, a także zagranicą. Poszukiwaniami objęto zatem zachowane księgi sądowe miast pruskich (w liczbie ponad 250 woluminów), zespoły akt rodzinno-majątkowych rodzin szlacheckich związanych z dzielnicą pruską, źródła proweniencji kościelnej zachowane 
w archiwach diecezjalnych diecezji toruńskiej, włocławskiej i pelplińskiej, w tym akta klasztorów. Poszukiwania w źródłach powstałych poza wspomnianą prowincją przeprowadzono m.in. w księgach sądów szlacheckich ziem pobliskich Prusom Królewskim, a więc w odpowiednich seriach ksiąg grodzkich z terenu Wielkopolski i Kujaw, następnie w wybranych zespołach źródeł wielu polskich archiwów i bibliotek, w których znajdują się lub spodziewano się znaleźć materiały do dziejów szlachty pruskiej, a także w Geheimes Staatsarchiv Preussicher Kulturbesitz w Berlinie Dahlem, Centralnym Państwowym Archiwum Historycznym Białorusi w Mińsku, Centralnym Państwowym Archiwum Historycznym Litwy w Wilnie, Lwowskiej Naukowej Bibliotece Akademii Nauk Ukrainy im. W. Stefanyka.

Wypada w tym miejscu podkreślić, że w sytuacji utraty ksiąg sądów szlacheckich przy poszukiwaniu testamentów za konieczną należy uznać kwerendę w księgach miejskich i kościelnych, w których szlachta miała możliwość dokonywania wpisów i oblat aktów ostatniej woli. Podobnie podstawowym sposobem postępowania przy tego rodzaju edycjach źródłowych winno być prowadzenie poszukiwań w księgach sądów szlacheckich województw i ziem sąsiednich. Wprawdzie w przypadku wydawców testamentów pruskich nie przyniosło to spodziewanych efektów (kwerendę określono jako „dłuższą i w sumie nieefektywną” - s. 29), jednak są na to wyraźne dowody, np. dla źródeł z terenu województwa sandomierskiego. I tak, w wydawnictwie testamentów z województwa sandomierskiego na 25 szlacheckich aktów ostatniej woli pięć pochodzi z ksiąg grodzkich krakowskich, zaś jeden z lubelskich ${ }^{18}$. Wydane ostatnio akty podziałów dóbr ziemskich szlachty sandomierskiej z XVII wieku również zdecydowanie o tym zaświadczają: wśród 30 dokumentów podziałowych, 17 wydobyto z ksiąg krakowskich, po jednym z bieckich i lubelskich ${ }^{19}$.

Przeprowadzona przez wydawców kwerenda źródłowa zaowocowała odnalezieniem 130 aktów ostatniej woli szlachty Prus Królewskich, spośród których odrzucono te, które - jakkolwiek sporządzone na obszarze prowincji - nie dotyczyły tutejszej szlachty (s. 21), a także testamenty wy-

${ }_{18}$ Cui contingit nasci..., nr 19, 23, 29, 30, 34, 35.

19 Źródta i materiaty do dziejów szlachty województwa sandomierskiego $w$ XVI-XVIII wieku, t. 3..., nr 2, 5-7, 9, 11-15, 18-20, 22-26, 29. 
dane w XIX-XX wieku (s. 20). Pominięcie dokumentów w pierwszym przypadku nie wymaga szerszego komentarza - już sam tytuł publikacji informuje bowiem, że zawiera ona jedynie testamenty, które odnoszą się do przedstawicieli miejscowej szlachty ${ }^{20}$. Wątpliwości nasuwają się natomiast w związku z decyzją o niezamieszczeniu 10 aktów ostatniej woli ogłoszonych wcześniej drukiem, z których kilka wydanych zostało w okresie do drugiej wojny światowej. Wydawcy wskazali przy tym na postępującą dostępność starszych prac z zawartymi w nich testamentami w digitalizowanych zasobach polskich bibliotek (s. 20-21). Moim zdaniem, o ile rezygnacja z powtarzania nowszych edycji pojedynczych testamentów była uzasadniona, o tyle testamenty najwcześniej podane do druku należało jednak ponownie opublikować ${ }^{21}$. Jak wiadomo bowiem, w drugiej połowie XIX wieku i początkach następnego stulecia dokumenty tego typu wydawano zazwyczaj bez odpowiadającego potrzebom współczesnych badań aparatu naukowego, w związku z czym źródła te zmuszają każdorazowo czytelnika do rozwiązywania szeregu zagadek szczegółowych (identyfikacja osób, miejscowości itp.). Argument o łatwiejszej ich dostępności w Internecie w porównaniu np. z testamentem Barbary z Dulskich Tarłowej, wydanym współcześnie, „lecz w lokalnym, niskonakładowym wydawnictwie” (s. 20), nie trafia do przekonania - przecież nawet niewielkie samoistne opracowania i czasopisma o zasięgu lokalnym znajdują się na półkach największych polskich bibliotek. Trudno poza tym przypuszczać, aby coraz liczniejsze rzesze badaczy analizujących testamenty, mając do dyspozycji zbiór ponad stu testamentów szlachty pruskiej, docierały drogą elektroniczną jeszcze do tych kilku pozostałych. Szkoda tym większa, że w niektórych przypadkach wydawcy znali nie tylko dawne publikacje, ale również zachowane do dziś rękopisy tych dokumentów, pozwalające na edycję adekwatną do dzisiejszych wy-

${ }^{20}$ Odmienne założenie przyjął Paweł Klint, którego intencją jest - jak sam stwierdził - „ukazanie aktów ostatniej woli pochodzących z jednego regionu w określonym czasie", ale wydobytych z jednolitego zasobu źródłowego w postaci zachowanych ksiąg grodzkich wielkopolskich. Zob.: Testamenty szlacheckie z ksiag grodzkich wielkopolskich z lat 1631-1655..., s. 11 .

${ }^{21}$ Zasadę taką przyjęto dla serii wydawniczej źródeł szlacheckich z województwa sandomierskiego. Zob.: Źródta i materiaty do dziejów szlachty województwa sandomierskiego w XVI-XVIII wieku, t. 1, op. cit., s. XVIII i t. 3, op. cit., s. XV. 
magań naukowych (s. 14 - testamenty wojewody malborskiego Samuela Żalińskiego i Franciszka Wejhera, starosty czarneńskiego i białoborskiego).

Warto w tym miejscu nadmienić, że szeroki zasięg wykonanej kwerendy skłonił wydawców do konstatacji, że „istnieje prawdopodobieństwo odnalezienia kilku kolejnych testamentów w zbiorach bezpośrednio niezwiązanych z Prusami Królewskimi” (s. 31). Stwierdzenie to wydaje się, moim zdaniem, zbyt pesymistyczne. Jak zauważyli sami wydawcy, już w edycji testamentów wielkopolskich zauważyli dwa akty ostatniej woli szlachty pruskiej (s. 18). Zważywszy ponadto na fakt, że przemieszczająca się po Rzeczypospolitej szlachta w każdym grodzie mogła oblatować wieziony ze sobą dokument oraz znaną tendencję do wielokrotnego wpisywania do ksiąg różnych grodów tego samego $\mathrm{aktu}^{22}$, w niejednych księgach, nawet pochodzących z południa kraju, istnieją realne szanse odnalezienia łącznie większej niż sądzą wydawcy liczby aktów ostatniej woli szlachciców z Prus Królewskich. Trudno np. zakładać, że wśród 2000 znanych Alicji Falniowskiej-Gradowskiej testamentów z ksiąg województwa krakowskiego $^{23}$ nie znajdą się także ostatnie dyspozycje szlachty pruskiej.

Wysuwane tu przypuszczenie wydaje się uzasadnione także w związku z zaproponowaną przez wydawców omawianej edycji - trafną moim zdaniem - definicją terrigeny pruskiego. Uznając wybiórczość podejścia ówczesnych do używania indygenatu pruskiego, przyjęli oni, że szlachta pruska to nie tylko reprezentanci rodów od pokoleń mieszkających na terenie prowincji, ale także pierwsi (lub jedyni) „przedstawiciele rodzin osiadłych na stałe w tej dzielnicy - protoplastów linii pruskich" oraz

osoby, które opuściły Prusy Królewskie, czy to poprzez nabycie nowych majątków i osiedlenie się w innych dzielnicach, czy poprzez związki małżeńskie (najczęściej w wypadku kobiet), przenosząc się do majątków współmałżonków, ale wyłącznie w pierwszym pokoleniu (s. 19).

22 Tak np. sporządzony 11 I 1651 r. akt podziału dóbr po kanclerzu Jerzym Ossolińskim tego samego dnia oblatowany został w grodzie warszawskim, 27 I wniesiony do grodu sandomierskiego, a 13 XI t. r. podany do ksiąg grodzkich wieluńskich. Zob.: J. Pielas, Podziaty majątkowe..., s. 156.

23 Testamenty szlachty krakowskiej..., s. VIII. 
Nie ulega bowiem wątpliwości, że to właśnie fakt posiadania majątku w konkretnych granicach administracyjnych decydował o uznaniu szlachcica za przynależącego do grona miejscowych terrigenów (vide m.in.: zasada osiadłości przy obejmowaniu określonych kategorii urzędów), nawet jeśli znacząca część jego aktywności publicznej zogniskowana była na innym obszarze Rzeczypospolitej. Nie musiało się to natomiast potwierdzać już w drugim pokoleniu - divisio bonorum terrestrium ojca, zwłaszcza wśród szlachty zamożnej i magnaterii, niejednokrotnie przeprowadzano bowiem w ten sposób, że synowie obejmowali działy w różnych częściach Rzeczypospolitej. Dla przykładu: czterej synowie Piotra Brzechwy, podkomorzego wendeńskiego (1637-1641), związanego z Inflantami, w 1654 roku podzielili ojcowiznę w ten sposób, że najstarsi - Kacper i Piotr - odziedziczyli dobra ziemskie w województwie krakowskim, powiecie czchowskim, średni, Gabriel, majątek w województwie sandomierskim, powiecie chęcińskim, najmłodszy Rafał zaś w województwie i powiecie krakowskim ${ }^{24}$. Jeszcze chyba większe prawdopodobieństwo odnalezienia kolejnych testamentów należy przyjąć w przypadku szlachcianek pruskich, które w związku z zawartym związkiem małżeńskim przeniosły się do mężowskiego dworku w innych częściach Rzeczypospolitej.

Określony zasób archiwalny, w którym przeprowadzona została kwerenda źródłowa, siłą rzeczy wpłynął na nadreprezentację pewnych grup testatorów. Wykorzystanie licznych źródeł wytworzonych przez instytucje Kościoła katolickiego spowodowało, że wśród 111 aktów ostatniej woli widzimy jedynie czterech przedstawicieli szlachty ewangelickiej (s. 38). Brak ksiąg sądów szlacheckich nie pozostał zapewne bez wpływu także na fakt, że w publikowanym zbiorze znalazło się tylko 13 testamentów urzędników ziemskich (w tym pięciu senatorów: trzech kasztelanów, dwóch wojewodów), jeden urzędnik nadworny i dwóch urzędników grodzkich. Dla porządku należy odnotować, że w publikacji znalazło się 39 testamentów kobiet (w tym dwóch żon senatorów), także testamenty wspólne - matki z córką oraz trzech małżeństw. Zasługą autorów jest tu również zwrócenie uwagi na szlacheckie ordynacje majątkowe lub dotyczące opieki i wykształ-

${ }^{24}$ Źródta $i$ materiaty do dziejów szlachty województwa sandomierskiego $w$ XVI-XVIII wieku, t. 3, op. cit., nr 18. 
cenia potomstwa, które niejednokrotnie mylone są przez badaczy z testamentami (s. 23). Pod względem ilości podanych do druku aktów ostatniej woli omawiane wydawnictwo ustępuje jedynie opracowanej przez Pawła Klinta najnowszej edycji testamentów z ksiąg grodzkich wielkopolskich. Należy podkreślić fakt, że w wyniku podjętych poszukiwań wydawcy odnaleźli również testamenty szlachty pruskiej z wieków XVI i XVIII, które przygotowują do kolejnej książkowej edycji.

Jak już wspomniano, mocną stroną edycji jest znacznych rozmiarów wstęp, w którym wydawcy odnieśli się do szeregu kwestii związanych ze znaczeniem testamentu jako źródła historycznego. W odniesieniu do wstępu chciałbym poczynić kilka uwag o charakterze szczegółowym. Zdając sobie sprawę, że wydawcy nie chcieli nadmiernie przeciążać słowa wstępnego przypisami, wydaje się jednak, że przy prezentacji budowy testamentu i zawartych w nich treści mogli wskazać - prócz sumiennego studium Bożeny Popiołek - także inne opracowania podejmujące to zagadnienie $^{25}$. Jednocześnie nasuwa się pytanie: czy niezbędne było liczące pół strony wymienianie kolejnych aktów ostatniej woli, które nie zawierają intytulacji? Warto podkreślić, że wydawcy zaprezentowali we wstępie interesujące wnioski wynikające $\mathrm{z}$ analizy formalnej areng zawartych $\mathrm{w}$ publikowanych testamentach, a więc tego elementu aktu ostatniej woli, który zazwyczaj przekazuje najwięcej informacji o testatorze, jego wykształceniu, religijności, obrazie świata i poglądach. Wynotowali najczęściej pojawiające się w arengach cytaty, w zdecydowanej większości pochodzące z Pisma Świętego, i dokonali ich ilościowych zestawień. Pozwoliło to wskazać na preferencję (swego rodzaju „modę”?) do wykorzystywania w testamentach konkretnych fragmentów z Ewangelii. Podobnie ciekawe walory poznawcze przynosi zestawienie liczby legatów przeznaczonych dla poszczególnych zgromadzeń zakonnych, których losy w Prusach Królewskich wydawcy w skrócie przypomnieli.

25 B. Popiołek, Woli mojej ostatniej Testament ten... testamenty staropolskie jako źródto do historii mentalności XVII i XVIII wieku, Kraków 2009. Por. m.in.: G. Jawor, State formuty $w$ testamentach polskich [XVI-XIX w.], „Rozprawy Komisji Językowej” 1981, t. 12, s. 217-233; L. Tymiakin, O formutach $w$ XVII-wiecznym testamencie przemyskim, „Rocznik Przemyski” 1990, t. 27, s. 141-145; Testamenty szlachty krakowskiej..., s. XIV; Cui contingit nasci..., s. 7-8. 
Stosowne miejsce wydawcy poświęcili nieodłącznemu elementowi szlacheckich aktów ostatniej woli, a więc rozporządzeniu majątkowemu. Podkreślając oczywistą przydatność testamentów do badań nad różnorodnymi aspektami funkcjonowania stanu szlacheckiego $\mathrm{w}$ dawnej Polsce ${ }^{26}$, zgadzam się z zamieszczonym w tej części wstępu stwierdzeniem J. Kowalkowskiego i W. Nowosada, że rozporządzenie majątkowe

\section{[...] to niewątpliwie jeden $\mathrm{z}$ najważniejszych lub wręcz najważniejszy z elementów budowy testamentu, i to właśnie z jego powodu testament sporządzano (s. 46).}

Nawiązując do szeregu uregulowań prawnych, wspomniani badacze trafnie podsumowali, że "gromadzone przez całe życie ruchomości były rozdawane testamentami według upodobań testatora i zasług osób go otaczających” (s. 47). Można w tym miejscu dodać, że niekiedy spod dyspozycji testamentowej wychodziła część ruchomości, które w wyniku swego rodzaju wydziałów mobiliów wcześniej zostały przekazane przez testatora zazwyczaj o ich uprzednim rozdysponowaniu decydowała potrzeba chwili i konieczność spieniężenia mobiliów w kryzysowej sytuacji ${ }^{27}$. Wiadomo, że w wyniku decyzji testatora majątek ruchomy i pieniądze dostawały się w ręce określonej grupy odbiorców - instytucji i osób, takich jak świątynie, kaplice, szpitale, bractwa religijne, szkoły, współmałżonkowie, dzieci, rodzeństwo, krewni bliżsi i dalsi, służba i czeladź dworska oraz osoby niespokrewnione, w tym egzekutorzy testamentu. Warto przypomnieć, że, biorąc pod uwagę dziedziczenie ruchomości przez sukcesorów, mamy w testamentach wyraźnie do czynienia z dwiema przeciwstawnymi tendencjami: dążeniem do sprawiedliwego, czyli równego, obdzielenia majątkiem ruchomym spadkobierców lub też wyraźnego wyróżnienia jednego z nich co do ilości i wartości legatów testamentowych. Jednocześnie o przekazaniu konkretnych ruchomości w testamencie decydowała nie tylko wymierna wartość przedmiotów, ale także płeć potomstwa i związany z nią podział na rzeczy „panieńskie” i „męskie”28. Jak wiadomo, dobra nierucho-

26 Zob.: Cui contingit nasci..., s. 9.

27 Por. szerzej: J. Pielas, Podziaty majątkowe..., s. 297-302.

28 Por.: B. Popiołek, Woli mojej ostatniej Testament ten..., s. 139. 
me w Rzeczypospolitej szlacheckiej od początku XVI wieku z zasady wyłączone były spod dyspozycji testamentowej. W Prusach Królewskich, począwszy od ujednolicenia praw prowincji przez Kazimierza Jagiellończyka w 1476 roku po tzw. Korekturę Pruską, prawo regulowało to precyzyjnie. Prócz podanych przez wydawców uregulowań prawnych w tym zakresie warto podkreślić znaczenie konstytucji z 1505, 1510 (De testamentis condendis) i 1519 roku (De testamentis non confirmandis), potwierdzonych w 1676 roku, kiedy to przypomniano, że „dobra ziemskie [...] nieruchome, pod dyzpozycyą testamentową podpadać nie mogą ${ }^{29}$.

Chciałbym przy tej okazji doprecyzować twierdzenie wydawców testamentów szlachty pruskiej w kwestii faktycznego dysponowania nieruchomościami w szlacheckich testamentach: „[...] może dziwić, że testamenty, wbrew obowiązującemu prawu, od czasu do czasu przemycały takie dyspozycje [...]" (s. 48).

Istotnie, w praktyce sporządzania szlacheckich testamentów niekiedy podawano wskazówki i dyspozycje co do losów pozostawianego majątku ziemskiego ${ }^{30}$. Pojawianie się klauzul o dobrach nieruchomych wiązało się przede wszystkim z sumami pieniężnymi zabezpieczonymi na majętnościach i dzierżawieniem dóbr. Wskazując na obciążenie majątków, testatorzy przypominali często fakt uprzedniego uczynienia przez siebie określonych zapisów w grodach. Nawet jeśli testatorzy okazywali swą wolę co do pożądanych losów majątku ziemskiego lub jego części po swej śmierci, byli wówczas świadomi konieczności uczynienia odrębnych zapisów w księgach grodzkich. Nieco inaczej traktowano sugestie testatorów co do dóbr ziemskich pozostawianych w opiece. Decyzje podjęte przez opiekunów

${ }^{29}$ Konstytucja z 1505 r. mówiła, że testamenta super bonis immobilibus facta sunt roboris nullaque reputentur, z 1510 r.: [...] decernimus, ut testamenta condantur [...] de bonis mobilibus. Immobilia vero bona, tam haereditaria, quam oppignorata [...] testamentali ordinationis subjecta minine essee debent. Por.: J. Pielas, Podziaty majatkowe..., s. 29.

30 Por.: B. Popiołek, Woli mojej ostatniej Testament ten..., s. 117-118; M. Beślerzewska, Szlacheckie pożegnanie z życiem. Testamenty z wielkopolskich ksiag grodzkich z lat 1702 -1723, „Genealogia. Studia i Materiały Historyczne” 2006, t. 18, s. 94; M. WilczekKarczewska, Konflikty rodzinne na tle majątkowym w świetle wielkopolskich inwentarzy i testamentów z XVII wieku. Zarys problematyki, [w:] Spoteczeństwo staropolskie. Seria nowa, t. 3: Spoteczeństwo a rodzina, red. A. Karpiński, Warszawa 2011 s. 157-158. 
pod wpływem wskazówek testamentowych spadkodawcy w istotny sposób zmieniały bowiem stan majątkowy spadkobierców (chociażby w przypadku sprzedaży części dóbr ziemskich). Nieznaczny procent testamentów przynosi wzmianki co do oczekiwanych przez testatora losów własności dziedzicznej po jego śmierci i podziału majątku między sukcesorami. Z reguły są to wówczas jedynie krótkie informacje o już przeprowadzonych wydziałach oraz napomnienia skierowane do spadkobierców o dokonanie równego podziału nieruchomości. Zważywszy na zasady prawa spadkowego zakładające identyczną wartość działów, wskazówki te nie miały wpływu na praktykę dziedziczenia nieruchomości. Szlachta doskonale zdawała sobie sprawę z uwarunkowań prawnych i stopni dziedziczenia, stąd też z szeregu aktów ostatniej woli przebija absolutna pewność spadkodawców o sukcesji osób będących spadkobiercami koniecznymi majątku ziemskiego. W tej sytuacji nie ulega wątpliwości, że rozporządzenia takowe były jedynie stwierdzeniem prawa sukcesorów do spadku w dobrach nieruchomych. Część testatorów wzmiankujących o swych dobrach ziemskich zwracała się do sukcesorów o aprobatę podjętych przez siebie działań majątkowych lub udzielała im dokładniejszych dyspozycji. Sprzedaż przez testatora części dóbr ziemskich na rzecz osób spoza grona spadkobierców, potwierdzona odpowiednimi zapisami, powodowała, że sukcesorzy byli w sytuacji przymusowej - konieczności zaakceptowania tych transakcji; jeżeli natomiast transakcje te nie zostały uprzednio poświadczone, przed spadkobiercami stawała konieczność rozpatrzenia prośby testatora. Ponadto niezwykle rzadko szlachta dokładniej charakteryzowała skład działów, które miały przypaść konkretnym sukcesorom. Tak więc w zakresie dóbr nieruchomych testament mógł wskazywać wolę spadkodawcy co do losów pozostawianych dóbr ziemskich, ale odnosiło się to do jego sukcesorów koniecznych. Nie istniał bowiem w ówczesnym prawie spadkowym przepis zabraniający rozporządzenia nieruchomościami na rzecz naturalnych spadkobierców ${ }^{31}$.

Godny odnotowania we wstępie do omawianej edycji źródłowej jest także fakt zwrócenia przez wydawców uwagi na problem wyznaczania

31 P. Dąbkowski, Prawo prywatne polskie, t. 2, Lwów 1911, s. 73. Por. szerzej: J. Pielas, „Przychylając się do woli i preordynacji ojcowskiej...”. Decyzje i wskazówki spadkodawców a ich respektowanie przez sukcesorów dóbr ziemskich w Koronie w XVII wieku (w druku). 
w aktach ostatniej woli opieki nad nieletnim potomstwem, niekiedy także nad ich matką; jak wiadomo, tutoria miała przede wszystkim na celu doprowadzenie dzieci do pełnoletniości i zachowania w odpowiednim stanie majątku należnego im prawem sukcesji (s. 50). To zagadnienie, niezwykle istotne z punktu widzenia funkcjonowania rodziny szlacheckiej w dobie staropolskiej, szczególnie w swej warstwie praktycznej, nie doczekało się jak dotąd należytego omówienia w literaturze historycznej ${ }^{32}$. Podobnie, brak bardziej szczegółowych badań nad kolejnym problemem zasygnalizowanym przez wydawców - kryteriami doboru egzekutorów przez testatora (warunkowanym przede wszystkim pozycją społeczną twórcy testamen$\mathrm{tu})^{33}$, liczbą egzekutorów oraz realizacją przez nich woli testamentowej. Jak dotąd polska historiografia nie dysponuje próbą szerszej charakterystyki zbiorowości egzekutorów aktów ostatniej woli oraz oceną ich rzeczywistych działań. Należy zgodzić się przy tym z obserwacją wydawców, że rzadko w testamentach szlacheckich odnaleźć można wzmianki poświadczające zjawisko wynagradzania wykonawców ostatniej woli (s. 51).

Przedstawione w końcowym fragmencie wstępu zasady przygotowania tekstów źródłowych do publikacji należy uznać za logiczne, spójne i zgodne z podstawowymi zasadami wydawania tekstów nowożytnych. Z lektury opublikowanych w językach polskim, łacińskim i niemieckim dokumentów przebija staranność i rzetelność w pracy nad źródłem kierowanym do druku. Zwraca uwagę zwłaszcza troska wydawców o identyfikację testatora, osób i miejscowości występujących w dokumentach (czy nie lepszym rozwiązaniem byłoby tu jednak podawanie przynależności administracyjnej miejscowości według podziałów obowiązujących w XVII w.?), które to informacje znakomicie ułatwiają analizę treści testamentów i formułowanie wniosków na temat badanych zagadnień. Jednocześnie zapo-

32 Podstawowe w dalszym ciagu w tej kwestii opracowanie ma charakter rozważań stricte prawnych i wnosi niewiele do wiedzy na temat praktyki wyznaczania i realizowania opieki nad małoletnimi w rodzinach szlacheckich w okresie wczesnonowożytnym. Zob.: W. Sobociński, Historia rządów opiekuńczych w Polsce, „Czasopismo Prawno-Historyczne” 1949, t. 2, s. 227-353.

33 M.in.: M. Borkowska OSB, op. cit., s. 13; B. Popiołek, Woli mojej ostatniej Testament ten..., s. 258-259; Testamenty szlacheckie z ksiag grodzkich wielkopolskich z lat 1631-1655..., s. 19-20. 
znanie się z przyjętymi przez wydawców testamentów szlachty pruskiej zasadami edytowania dokumentów prowadzi do następującej konkluzji: kolejni polscy wydawcy tekstów staropolskich, nie wyłączając piszącego te słowa, jakkolwiek powołują się na najpowszechniej używaną instrukcję wydawniczą dla źródeł od XVI do połowy XIX wieku pod redakcją Kazimierza Lepszego, opracowaną w 1953 roku $^{34}$, to jednak czynią od niej mniejsze lub większe odstępstwa, różnie je zresztą uzasadniając. Wyjątki te dotyczą przede wszystkim rezygnacji z pełnej modernizacji pisowni części wyrazów staropolskich, z zalecanej przez instrukcję formy typu „konstytucyja”, „prowincyjej” czy też przyjęcia zasady niemodernizowania nazwisk i nazw miejscowych. W tej sytuacji nieuchronnie rodzi się pytanie o przydatność wspomnianej instrukcji wydawniczej, a w dalszej perspektywie potrzeba (konieczność?) wypracowania nowej, respektowanej przez ogół lub zdecydowaną większość badaczy instrukcji wydawniczej dla źródeł z okresu staropolskiego.

Staranne podejście wydawców do materiału źródłowego i prezentacji słowa wstępnego przyniosło, moim zdaniem, publikację, w której właściwie nie dostrzega się błędów i usterek (poza kilkoma „literówkami” w rodzaju: Bandyra zamiast Bondyra - s. 11, przyp. 10; Kowalikowskiego zamiast Kowalkowskiego - s. 17).

Poczynione w niniejszym tekście uwagi, będące przede wszystkim wyrazem refleksji nad kształtem edycji źródeł do dziejów stanu uprzywilejowanego w sytuacji braku podstawowych zasobów źródłowych w postaci ksiąg sądów szlacheckich, w niczym nie umniejszają bardzo wysokiej oceny wydawnictwa testamentów szlachty Prus Królewskich przygotowanego przez Jacka Kowalkowskiego i Wiesława Nowosada. Omówione wydawnictwo z całą pewnością znajdzie się w podstawowym kanonie wydawnictw testamentów staropolskich, których sukcesywne udostępnianie drukiem przyczynia się do wyraźnego ożywienia badań nad różnorodnymi aspektami funkcjonowania stanu szlacheckiego, w tym staropolską „sztuką umierania”, genealogiami rodów szlacheckich, charakterystycznymi przejawami barokowej religijności, więziami rodzinnymi i konfliktami

${ }^{34}$ Instrukcja wydawnicza dla źródet historycznych od XVI do potowy XIX wieku, red. K. Lepszy, Wrocław 1953. 
wśród krewnych, wyposażeniem siedzib szlacheckich czy też mentalnością i sprawami majątkowymi szlachty i magnatów w dawnej Rzeczypospolitej. $\mathrm{Z}$ nadzieją i pozytywnym nastawieniem należy więc oczekiwać na zapowiadane przez wydawców kolejne edycje aktów ostatniej woli szlachty Prus Królewskich.

Jacek Pielas (Kielce) 